\title{
LEVEL II SCOUR ANALYSIS FOR BRIDGE 49 (BRIDTH00530049) on TOWN HIGHWAY 53, crossing the NORTH BRANCH OTTAUQUECHEE RIVER, BRIDGEWATER, VERMONT
}

U.S. Geological Survey Open-File Report 96-407

Prepared in cooperation with

VERMONT AGENCY OF TRANSPORTATION and FEDERAL HIGHWAY ADMINISTRATION 


\section{LEVEL II SCOUR ANALYSIS FOR}

BRIDGE 49 (BRIDTH00530049) on

TOWN HIGHWAY 53, crossing the

NORTH BRANCH OTTAUQUECHEE

RIVER,

BRIDGEWATER, VERMONT

By MICHAEL A. IVANOFF and SCOTT A. OLSON

U.S. Geological Survey

Open-File Report 96-407

Prepared in cooperation with

VERMONT AGENCY OF TRANSPORTATION

and

FEDERAL HIGHWAY ADMINISTRATION 


\title{
U.S. DEPARTMENT OF THE INTERIOR BRUCE BABBITT, Secretary
}

\author{
U.S. GEOLOGICAL SURVEY \\ Gordon P. Eaton, Director
}

For additional information write to:

District Chief

U.S. Geological Survey 361 Commerce Way

Pembroke, NH 03275
Copies of this report may be purchased from:

U.S. Geological Survey Earth Science Information Center Open-File Reports Section Box 25286, MS 517 Federal Center

Denver, CO 80225 


\section{CONTENTS}

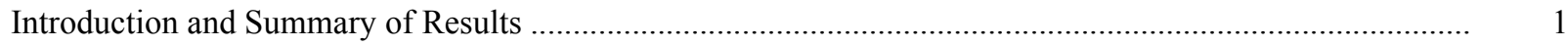

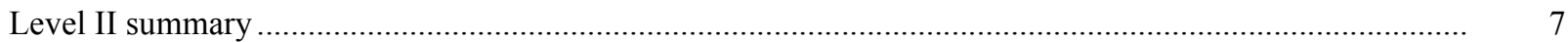

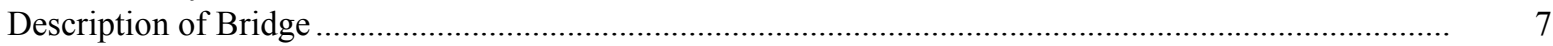

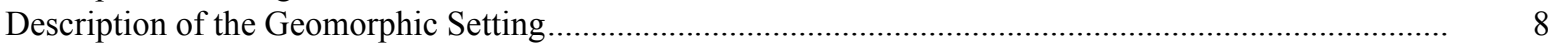

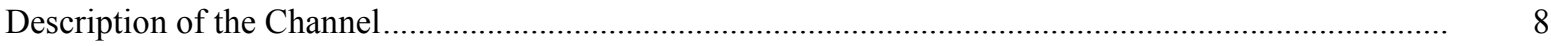

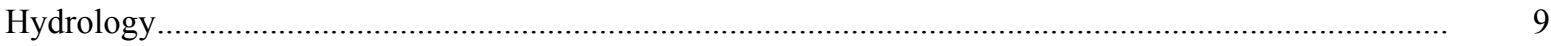

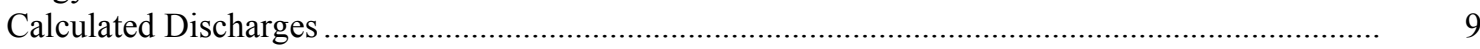

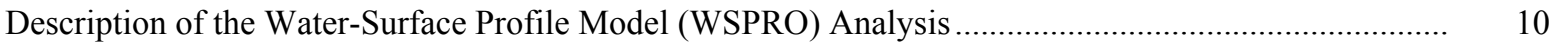

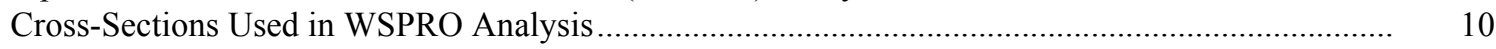

Data and Assumptions Used in WSPRO Model ...................................................................... 11

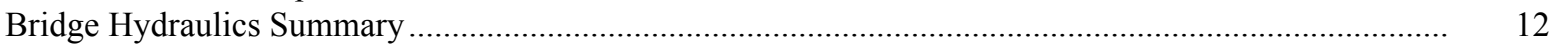

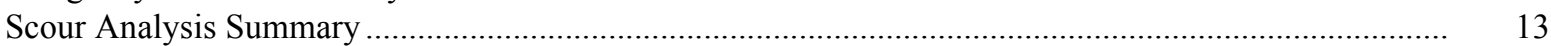

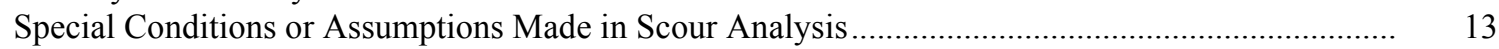

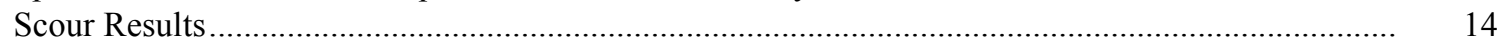

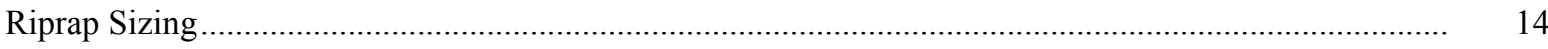

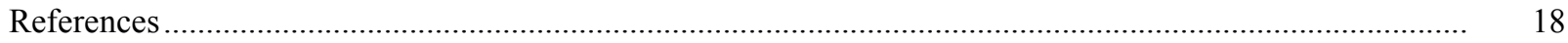

Appendixes:

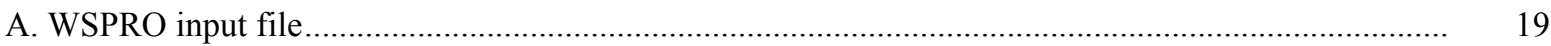

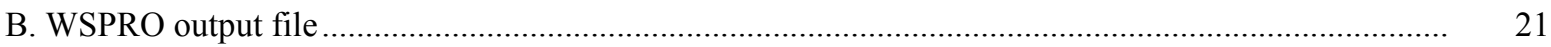

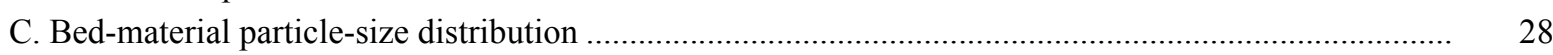

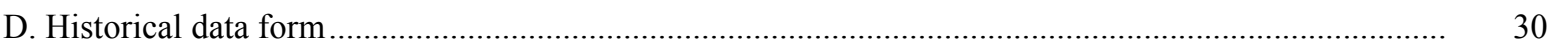

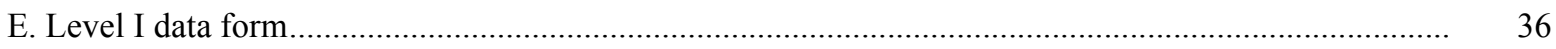

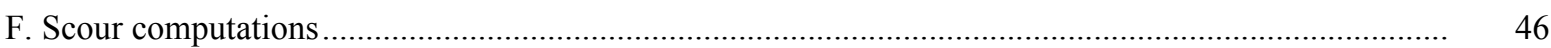

\section{FIGURES}

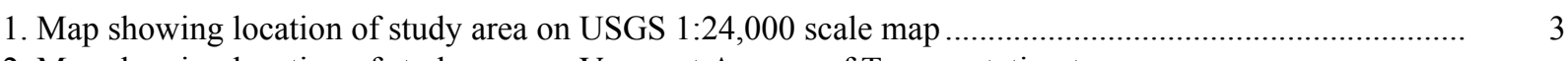

2. Map showing location of study area on Vermont Agency of Transportation town
highway map

3. Structure BRIDTH00530049 viewed from upstream (October 27, 1994) ...............................................

4. Downstream channel viewed from structure BRIDTH00530049 (October 27, 1994) ........................... 5

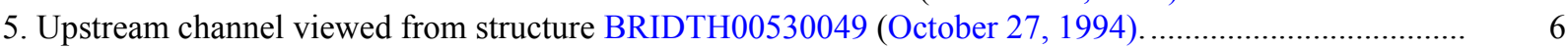

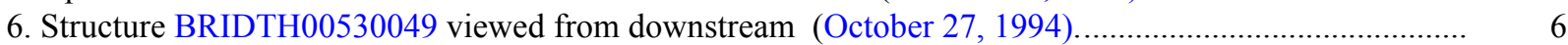

7. Water-surface profiles for the 100- and 500-year discharges at structure BRIDTH00530049 on Town Highway 53, crossing the North Branch Ottauquechee River, Bridgewater, Vermont.

8. Scour elevations for the 100- and 500-year discharges at structure BRIDTH00530049 on Town Highway 53, crossing the North Branch Ottauquechee River, Bridgewater, Vermont.

\section{TABLES}

1. Remaining footing/pile depth at abutments for the 100-year discharge at structure

BRIDTH00530049 on Town Highway 53, crossing the North Branch Ottauquechee River,

Bridgewater, Vermont

2. Remaining footing/pile depth at abutments for the 500-year discharge at structure

BRIDTH00530049 on Town Highway 53, crossing the North Branch Ottauquechee River,

Bridgewater, Vermont. 3
5
5
6
6 5

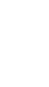




\begin{tabular}{|c|c|c|}
\hline Multiply & By & To obtain \\
\hline \multicolumn{3}{|c|}{ Length } \\
\hline inch (in.) & 25.4 & millimeter (mm) \\
\hline foot $(\mathrm{ft})$ & 0.3048 & $\operatorname{meter}(\mathrm{m})$ \\
\hline mile (mi) & 1.609 & kilometer (km) \\
\hline \multicolumn{3}{|c|}{ Slope } \\
\hline foot per mile ( $\mathrm{ft} / \mathrm{mi})$ & 0.1894 & meter per kilometer $(\mathrm{m} / \mathrm{km})$ \\
\hline \multicolumn{3}{|c|}{ Area } \\
\hline square mile $\left(\mathrm{mi}^{2}\right)$ & 2.590 & square kilometer $\left(\mathrm{km}^{2}\right)$ \\
\hline \multicolumn{3}{|c|}{ Volume } \\
\hline cubic foot $\left(\mathrm{ft}^{3}\right)$ & $\begin{array}{l}0.02832 \\
\text { Velocity and Flow }\end{array}$ & cubic meter $\left(\mathrm{m}^{3}\right)$ \\
\hline foot per second $(\mathrm{ft} / \mathrm{s})$ & 0.3048 & meter per second $(\mathrm{m} / \mathrm{s})$ \\
\hline cubic foot per second $\left(\mathrm{ft}^{3} / \mathrm{s}\right)$ & 0.02832 & cubic meter per second $\left(\mathrm{m}^{3} / \mathrm{s}\right)$ \\
\hline $\begin{array}{l}\text { cubic foot per second per } \\
\text { square mile } \\
{\left[\left(\mathrm{ft}^{3} / \mathrm{s}\right) / \mathrm{mi}^{2}\right]}\end{array}$ & 0.01093 & $\begin{array}{l}\text { cubic meter per } \\
\text { second per square } \\
\text { kilometer }\left[\left(\mathrm{m}^{3} / \mathrm{s}\right) / \mathrm{km}^{2}\right]\end{array}$ \\
\hline
\end{tabular}

OTHER ABBREVIATIONS

$\begin{array}{lrlr}\mathrm{BF} & \text { bank full } & \text { LWW } & \text { left wingwall } \\ \mathrm{cfs} & \text { cubic feet per second } & \text { MC } & \text { main channel } \\ \mathrm{D}_{50} & \text { median diameter of bed material } & \text { RAB } & \text { right abutment } \\ \mathrm{DS} & \text { downstream } & \text { RABUT } & \text { face of right abutment } \\ \mathrm{elev} & \text { elevation } & \text { RB } & \text { right bank } \\ \mathrm{f} / \mathrm{p} & \text { flood plain } & \text { ROB } & \text { right overbank } \\ \mathrm{ft} & \text { square feet } & \text { RWW } & \text { right wingwall } \\ \mathrm{ft} / \mathrm{ft} & \text { feet per foot } & \text { TH } & \text { town highway } \\ \mathrm{JCT} & \text { junction } & \text { UB } & \text { under bridge } \\ \mathrm{LAB} & \text { left abutment } & \text { US } & \text { upstream } \\ \mathrm{LABUT} & \text { face of left abutment } & \text { USGS } & \text { United States Geological Survey } \\ \text { LB } & \text { left bank } & \text { VTAOT Vermont Agency of Transportation } \\ \text { LOB } & \text { left overbank } & \text { WSPRO } & \text { water-surface profile model }\end{array}$

In this report, the words "right" and "left" refer to directions that would be reported by an observer facing downstream. Sea level: In this report, "sea level" refers to the National Geodetic Vertical Datum of 1929-- a geodetic datum derived from a general adjustment of the first-order level nets of the United States and Canada, formerly called Sea Level Datum of 1929.

In the appendices, the above abbreviations may be combined. For example, USLB would represent upstream left bank. 


\title{
LEVEL II SCOUR ANALYSIS FOR BRIDGE 49 (BRIDTH00530049) ON TOWN HIGHWAY 53, CROSSING THE NORTH BRANCH OTTAUQUECHEE RIVER, BRIDGEWATER, VERMONT
}

\author{
By Michael A. Ivanoff and Scott A. Olson
}

\section{INTRODUCTION AND SUMMARY OF RESULTS}

This report provides the results of a detailed Level II analysis of scour potential at structure BRIDTH00530049 on town highway 53 crossing the North Branch of the Ottauquechee River, Bridgewater, Vermont (figures 1-8). A Level II study is a basic engineering analysis of the site, including a quantitative analysis of stream stability and scour (U.S. Department of Transportation, 1993). Results of a Level I scour investigation also are included in Appendix E of this report. A Level I investigation provides a qualitative geomorphic characterization of the study site. Information on the bridge available from VTAOT files was compiled prior to conducting Level I and Level II analyses and can be found in Appendix D.

The site is in the Green Mountain physiographic province of central Vermont in the town of Bridgewater. The 26.6- $\mathrm{mi}^{2}$ drainage area is in a predominantly rural and forested basin. In the vicinity of the study site, the immediate banks have woody vegetation coverage with grass on the overbanks.

In the study area, the North Branch Ottauquechee River has a sinuous channel with a slope of approximately $0.0075 \mathrm{ft} / \mathrm{ft}$, an average channel top width of $66 \mathrm{ft}$ and an average channel depth of $6 \mathrm{ft}$. The predominant channel bed material is cobble and gravel $\left(\mathrm{D}_{50}\right.$ is $68.4 \mathrm{~mm}$ or $0.224 \mathrm{ft}$ ). The geomorphic assessment at the time of the Level I and Level II site visit on October 27, 1994, indicated that the reach was stable.

The town highway 53 crossing of the North Branch of the Ottauquechee River is a 51-ftlong, one-lane bridge consisting of one 49-foot steel-beam span (Vermont Agency of Transportation, written communication, August 25, 1994). The bridge is supported by vertical, concrete abutments with wingwalls. The channel is not skewed to the opening and the opening-skew-to-roadway is zero degrees.

The scour protection measures in place at the site are type- 1 stone fill (less than 12 inches diameter) along the upstream left wingwall and type-2 stone fill (less than 36 inches diameter) along the upstream right wingwall. Additional details describing conditions at the site are included in the Level II Summary and Appendices D and E. 
Scour depths and rock rip-rap sizes were computed using the general guidelines described in Hydraulic Engineering Circular 18 (Richardson and others, 1993).

Total scour at a highway crossing is comprised of three components: 1) long-term aggradation or degradation; 2) contraction scour (due to reduction in flow area caused by a bridge) and; 3) local scour (caused by accelerated flow around piers and abutments). Total scour is the sum of the three components. Equations are available to compute scour depths for contraction and local scour and a summary of the results follows.

Contraction scour for all modelled flows was 0 feet. Abutment scour ranged from 2.3 to 12.0 feet and the worst-case abutment scour also occurred at the 500-year discharge. Additional information on scour depths and depths to armoring are included in the section titled "Scour Results". Scoured-streambed elevations, based on the calculated scour depths, are presented in tables 1 and 2. A cross-section of the scour computed at the bridge is presented in figure 8. Scour depths were calculated assuming an infinite depth of erosive material and a homogeneous particle-size distribution.

It is generally accepted that the Froehlich equation (abutment scour) gives "excessively conservative estimates of scour depths" (Richardson and others, 1993, p. 47). Usually, computed scour depths are evaluated in combination with other information including (but not limited to) historical performance during flood events, the geomorphic stability assessment, existing scour protection measures, and the results of the hydraulic analyses. Therefore, scour depths adopted by VTAOT may differ from the computed values documented herein. 


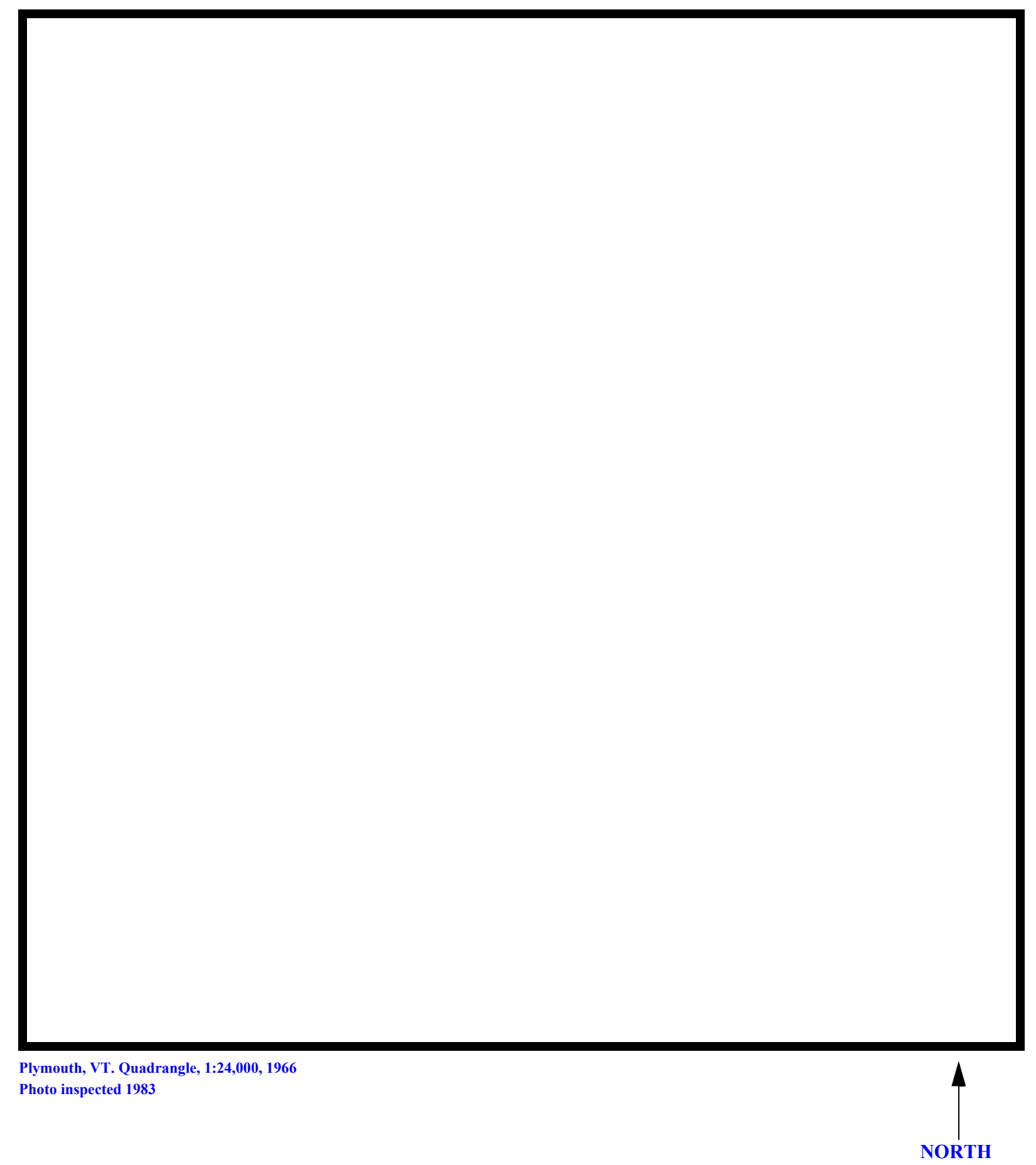

Figure 1. Location of study area on USGS 1:24,000 scale map. 
Figure 2. Location of study area on Vermont Agency of Transportation town highway map. 

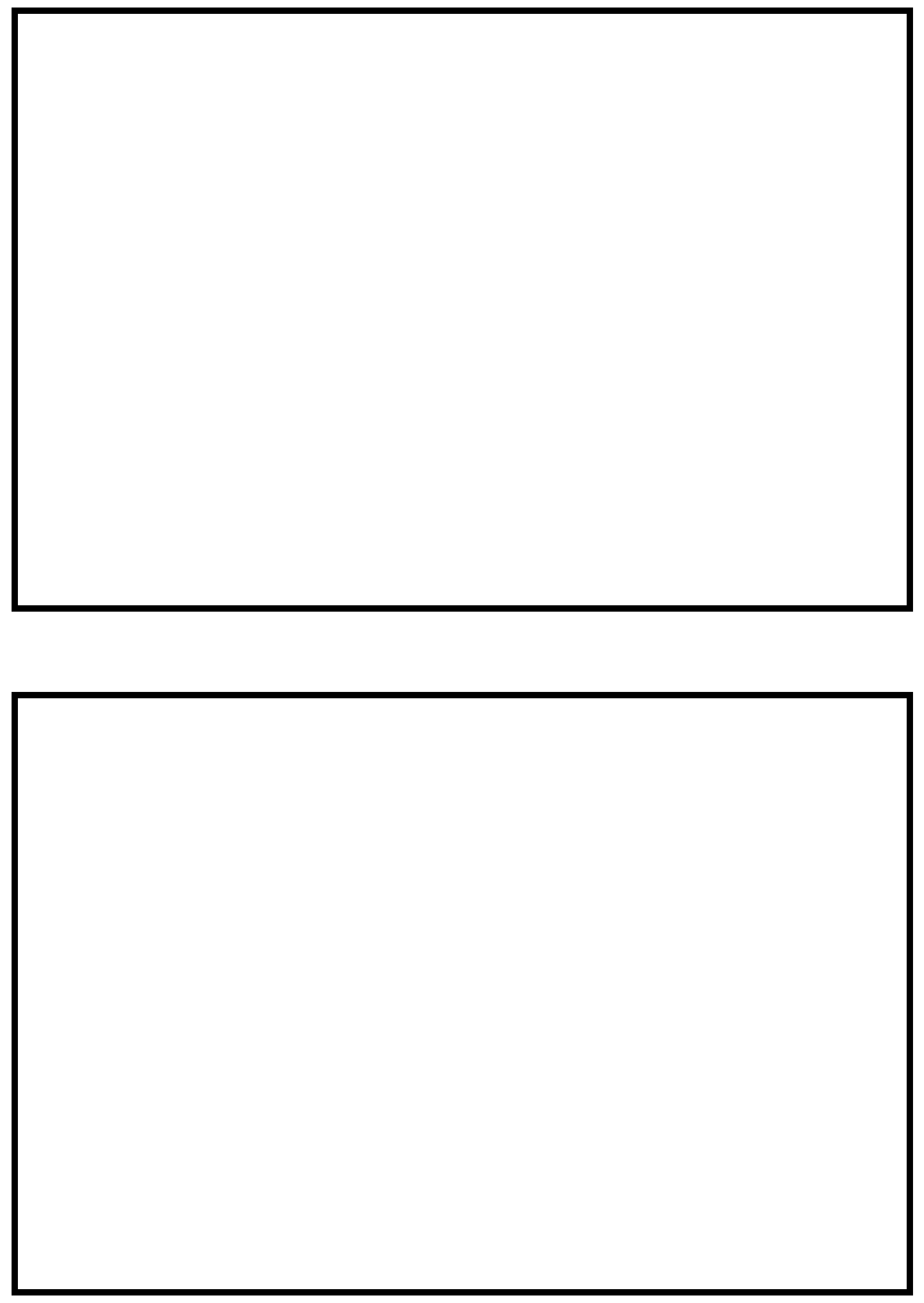

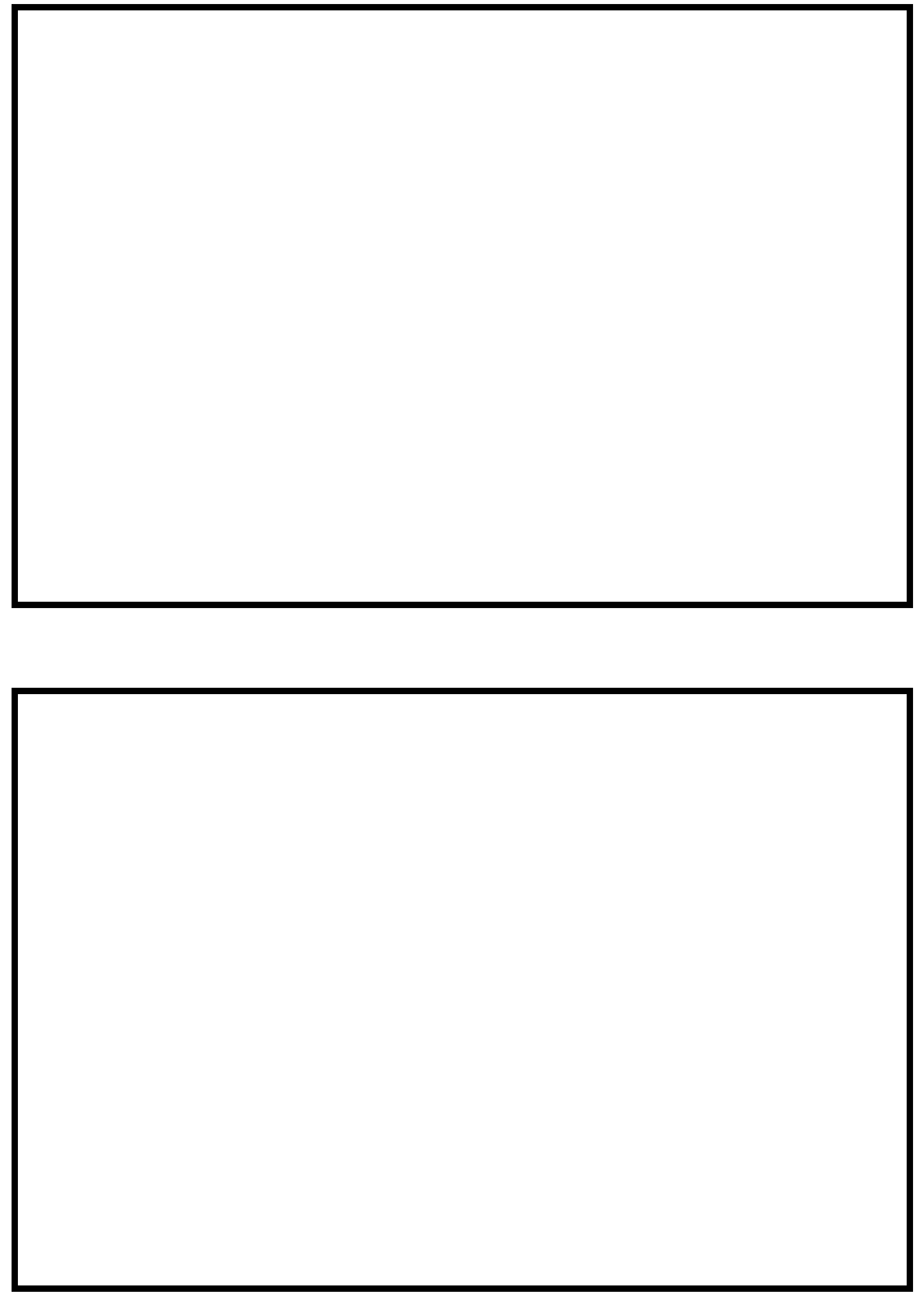


\section{LEVEL II SUMMARY}

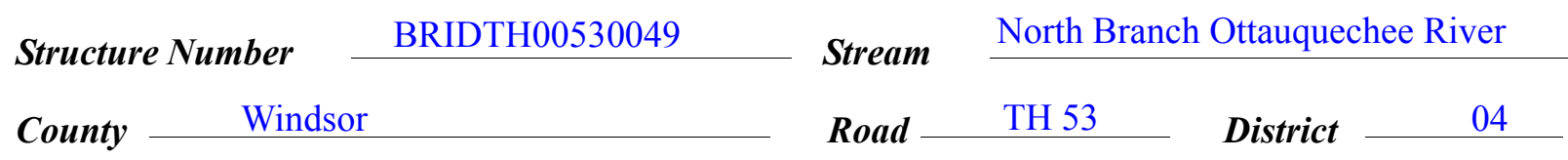

\section{Description of Bridge}

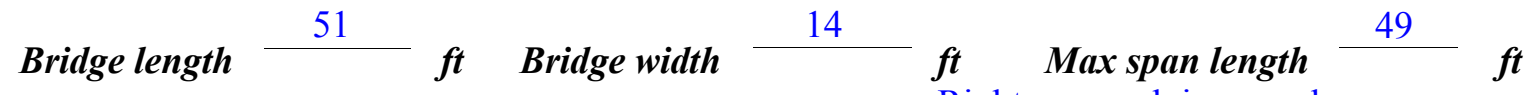
Alignment of bridge to road (on curve or straight) Abutment type Vertical

Stone fill on abutment? No Embankment type Right approach is curved nommintisu of atsw a fill Drto af incnortion Embankment type $\frac{\text { Sloping }}{$\cline { 2 - 2 } $10 / 27 / 94}$ right wingwall. Type-1, along the upstream left wingwall. Type-2, along the upstream rent

Abutments and wingwalls are concrete.

- . . . . . . .

\section{No}

Is bridge skewed to flood flow according to Yes ' survey?

Angle

There is a mild_channel bend in the upstream reach.

Debris accumulation on bridge at time of Level I or Level II site visit:

\begin{tabular}{|c|c|c|c|}
\hline & $\begin{array}{c}\text { Date of insnortion } \\
10 / 27 / 94 \\
\end{array}$ & $\begin{array}{l}\text { Percent of rhmmal } \\
\text { blocked inortzontatly }\end{array}$ & $\begin{array}{l}\text { Percent of } 0 \\
\text { blocked verticatty }\end{array}$ \\
\hline & $10 / 27 / 94$ & -- & -- \\
\hline & Low. & & \\
\hline
\end{tabular}

Potential for debris

10/27/94 -- None

Dosriho anv foaturos noar ar at tho hridoo that mav affort flow, (includo ahsorvation dato) 


\section{Description of the Geomorphic Setting}

General topography The channel is a high gradient upland stream with a flat to slightly irregular 370 feet wide flood plain and steep valley walls on both sides.

Geomorphic conditions at bridge site: downstream (DS), upstream (US)

Date of inspection $\quad 10 / 27 / 94$

DS left: $\quad$ Moderately sloped channel bank to a narrow flood plain

DS right: $\quad$ Moderately sloped channel bank to a narrow flood plain

US left: $\quad$ Moderately sloped channel bank to a narrow flood plain

US right: $\quad$ Moderately sloped channel bank to a narrow flood plain

\section{Description of the Channel}

\begin{tabular}{|c|c|c|c|c|}
\hline \multirow[b]{2}{*}{ Average top width } & 66 & \multirow[b]{2}{*}{ Average depth } & 6 & \multirow[b]{2}{*}{4} \\
\hline & $\stackrel{\boldsymbol{f t}}{\text { Gravel / Cobbles }}$ & & Gravel & \\
\hline Predominant bed mo & & Bank material & tly sinuo & us but \\
\hline
\end{tabular}

stable with alluvial channel boundaries and a narrow floö plain.

Vegetative co ${ }^{1}$ Trees on immediate bank with tall grasses and a paved road on overbank.

DS left: $\quad$ Trees on immediate bank with grass on overbank.

DS right: $\quad$ Trees on immediate bank with tall grasses and a paved road on overbank.

US left: $\quad$ Trees on immediate bank with grass and a gravel roadway on overbank.

US right: $\quad$ Yes

Do banks appear stable? 10/27/94 -- There is, a slight impact upon the upstream left bank date of observation.

10/27/94 -- None

Describe any obstructions in channel and date of observation. 


\title{
Hydrology
}

Drainage area $\quad 26.6 \boldsymbol{m i}^{2}$

Percentage of drainage area in physiographic provinces: (approximate)

Physiographic province

Green Mountain
Percent of drainage area

100

\begin{abstract}
Is drainage area considered rural or urban?
Rural urbanization: None.

Describe any significant
\end{abstract}

Is there a USGS gage on the stream of interest?

USGS gage description

USGS gage number

Gage drainage area

$m i^{2}$

No

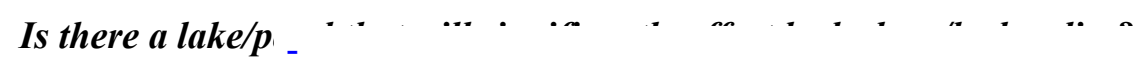

No 


\section{Description of the Water-Surface Profile Model (WSPRO) Analysis}

Datum for WSPRO analysis (USGS survey, sea level, VTAOT plans)

USGS survey

Datum tie between USGS survey and VTAOT plans

None

Description of reference marks used to determine USGS datum. $\quad$ RM1 is a chiseled X on

top of the US end of the right abutment (elev. $499.65 \mathrm{ft}$, arbitrary survey datum). RM2 is a

chiseled X on top of the DS end of the left abutment (elev. $499.67 \mathrm{ft}$, arbitrary survey datum).

\section{Cross-Sections Used in WSPRO Analysis}

\begin{tabular}{|c|c|c|c|}
\hline${ }^{1}$ Cross-section & $\begin{array}{c}\text { Section } \\
\text { Reference } \\
\text { Distance } \\
\text { (SRD) in feet }\end{array}$ & $\begin{array}{c}{ }^{2} \text { Cross-section } \\
\text { development }\end{array}$ & Comments \\
\hline EXITX & -67 & 1 & Exit section \\
\hline FULLV & 0 & 2 & $\begin{array}{l}\text { Downstream Full-valley } \\
\text { section (Templated from } \\
\text { EXITX) }\end{array}$ \\
\hline BRIDG & 0 & 1 & Bridge section \\
\hline RDWAY & 8 & 1 & Road Grade section \\
\hline APPRO & 69 & 1 & Approach section \\
\hline
\end{tabular}

${ }^{1}$ For location of cross-sections see plan-view sketch included with Level I field form, Appendix E. For more detail on how cross-sections were developed see WSPRO input file. 


\section{Data and Assumptions Used in WSPRO Model}

Hydraulic analyses of the reach were done by use of the Federal Highway Administration's WSPRO step-backwater computer program (Shearman and others, 1986, and Shearman, 1990). The analysis reported herein reflects conditions existing at the site at the time of the study. Furthermore, in the development of the model it was necessary to assume no accumulation of debris or ice at the site. Results of the hydraulic model are presented in the Bridge Hydraulic Summary, Appendix B, and figure 7.

Channel roughness factors (Manning's " $n$ ") used in the hydraulic model were estimated using field inspections at each cross section following the general guidelines described by Arcement and Schneider (1989). Final adjustments to the values were made during the modelling of the reach. Channel " $\mathrm{n}$ " values for the reach ranged from 0.040 to 0.046 , and overbank " $n$ " values were 0.035 .

Normal depth at the exit section (EXITX) was assumed as the starting water surface. This depth was computed by use of the slope-conveyance method outlined in the User's manual for WSPRO (Shearman, 1990). The slope used was $0.0075 \mathrm{ft} / \mathrm{ft}$ which was determined from downstream thalweg points.

The surveyed approach section (APPRO) was one bridge length upstream of the upstream face as recommended by Shearman and others (1986). This approach also provides a consistent method for determining scour variables.

The incipient overtopping discharge was determined to be $2,502 \mathrm{ft}^{3} / \mathrm{s}$. 


\section{Bridge Hydraulics Summary}

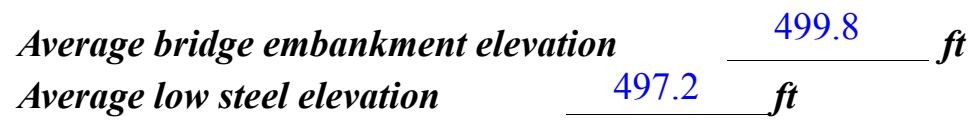

$$
\text { 100-year discharge } \quad 4,800 \quad \mathrm{ft}^{3} / \mathrm{s}
$$

Water-surface elevation in bridge opening $\quad 497.2 \quad f t$

Road overtopping? ___ Y Discharge over road _ 1,560, is

\begin{tabular}{lll} 
Area of flow in bridge opening & $413 \quad \boldsymbol{f t}^{\mathbf{2}}$ \\
\cline { 2 - 2 } Average velocity in bridge opening & 7.9 & $\mathrm{ft} / \mathrm{s}$
\end{tabular}

$\begin{array}{llll}\text { Maximum WSPRO tube velocity at bridge } & 8.9 & \mathrm{ft} / \mathrm{s}\end{array}$

Water-surface elevation at Approach section with bridge 498.5

Water-surface elevation at Approach section without bridge $\quad 497.6$

Amount of backwater caused by bridge $\quad 0.9 \quad$ it

500-year discharge $\quad 6,500 \quad \boldsymbol{f t}^{3} / \mathrm{s}$

Water-surface elevation in bridge opening $\quad 497.2 \mathrm{ft}$

Road overtopping? ___ Y Discharge over road__ $2,569, \mathrm{~J} / \mathrm{s}$

\begin{tabular}{llll} 
Area of flow in bridge opening & 413 & $\boldsymbol{f t}^{2}$ & \\
\cline { 2 - 3 } Average velocity in bridge opening & & 9.5 & $\mathbf{f t} / \mathbf{s}$
\end{tabular}

Maximum WSPRO tube velocity at bridge 10.7 /s

Water-surface elevation at Approach section with bridge 499.4

Water-surface elevation at Approach section without bridge $\quad 498.4$

Amount of backwater caused by bridge 1.0 .

Incipient overtopping discharge $\quad 2,502 \quad \mathrm{ft}^{3} / \mathrm{s}$

Water-surface elevation in bridge opening $494.5 \quad t$

\begin{tabular}{lllll} 
Area of flow in bridge opening & 286 & $\boldsymbol{f t}^{\mathbf{2}}$ & \\
\cline { 2 - 4 } Average velocity in bridge opening & & 8.7 & $\mathbf{f t} / \mathrm{s}$
\end{tabular}

Maximum WSPRO tube velocity at bridge $\quad 10.0 \mathrm{ft} / \mathrm{s}$

Water-surface elevation at Approach section with bridge

Water-surface elevation at Approach section without bridge

495.4

Amount of backwater caused by bridge $\quad$\begin{tabular}{ll}
0.0 it \\
\hline
\end{tabular} 


\section{Scour Analysis Summary}

\section{Special Conditions or Assumptions Made in Scour Analysis}

Scour depths were computed using the general guidelines described in Hydraulic Engineering Circular 18 (Richardson and others, 1993). Scour depths were calculated assuming an infinite depth of erosive material and a homogeneous particle-size distribution. The results of the scour analysis are presented in tables 1 and 2 and a graph of the scour depths is presented in figure 8 .

Contraction scour was computed by use of the Chang pressure-flow scour equation (Richardson and others, 1995, p. 145-146) for the 100-year and 500-year discharges. For the 100-year and 500-year discharges, there was orifice flow at the bridge. Contraction scour at bridges with orifice flow is best estimated by use of Chang pressure-flow scour equation (oral communication, J. Sterling Jones, October 4, 1996). The results of Laursen's clear-water contraction scour equation (Richardson and others, 1993, p. 35, equation 18) were also computed and can be found in appendix F. Contraction scour was computed by use of the clear-water contraction scour equation (Richardson and others, 1993, p. 35, equation 18) for the incipient road-overflow discharge. For contraction scour computations, the average depth in the contracted section (AREA/TOPWIDTH) is subtracted from the depth of flow computed by the scour equation (Y2) to determine the actual amount of scour.

Abutment scour at all modelled discharges was computed by use of the HIRE equation (Richardson and others, 1993, p. 50, equation 25) because the HIRE equation is recommended when the length to depth ratio of the embankment blocking flow exceeds 25 . Variables for the HIRE equation include the Froude number of the flow approaching the embankments, the length of the embankment blocking flow, and the depth of flow approaching the embankment less any roadway overtopping. 


\section{Scour Results}

\section{0-yr discharge 500-yr discharge}

Contraction scour:

(Scour depths in feet)

Main channel

Live-bed scour

Clear-water scour

Depth to armoring

Left overbank

Right overbank

Local scour:

Abutment scour

Left abutment

6.8

7.2

4.0

10.3

12.0

2.3-

Right abutment

Pier scour

Pier 1

Pier 2

Pier 3

\section{Abutments:}

Left abutment

Right abutment

Piers:

Pier 1

Pier 2

overtopping discharge 


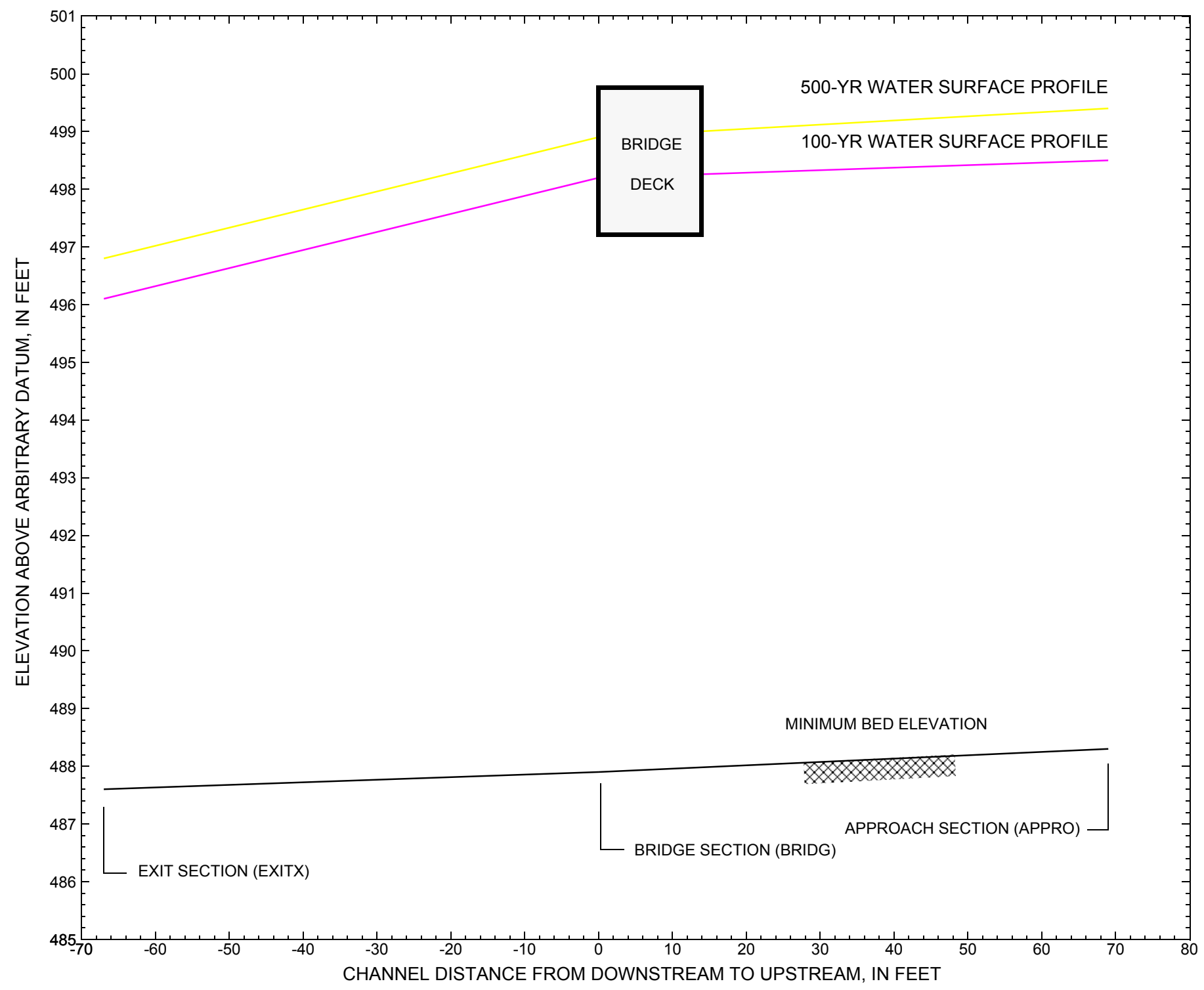

Figure 7. Water-surface profiles for the 100- and 500-yr discharges at structure BRIDTH00530049 on town highway 53, crossing Ottauquechee River, Bridgewater, Vermont. 


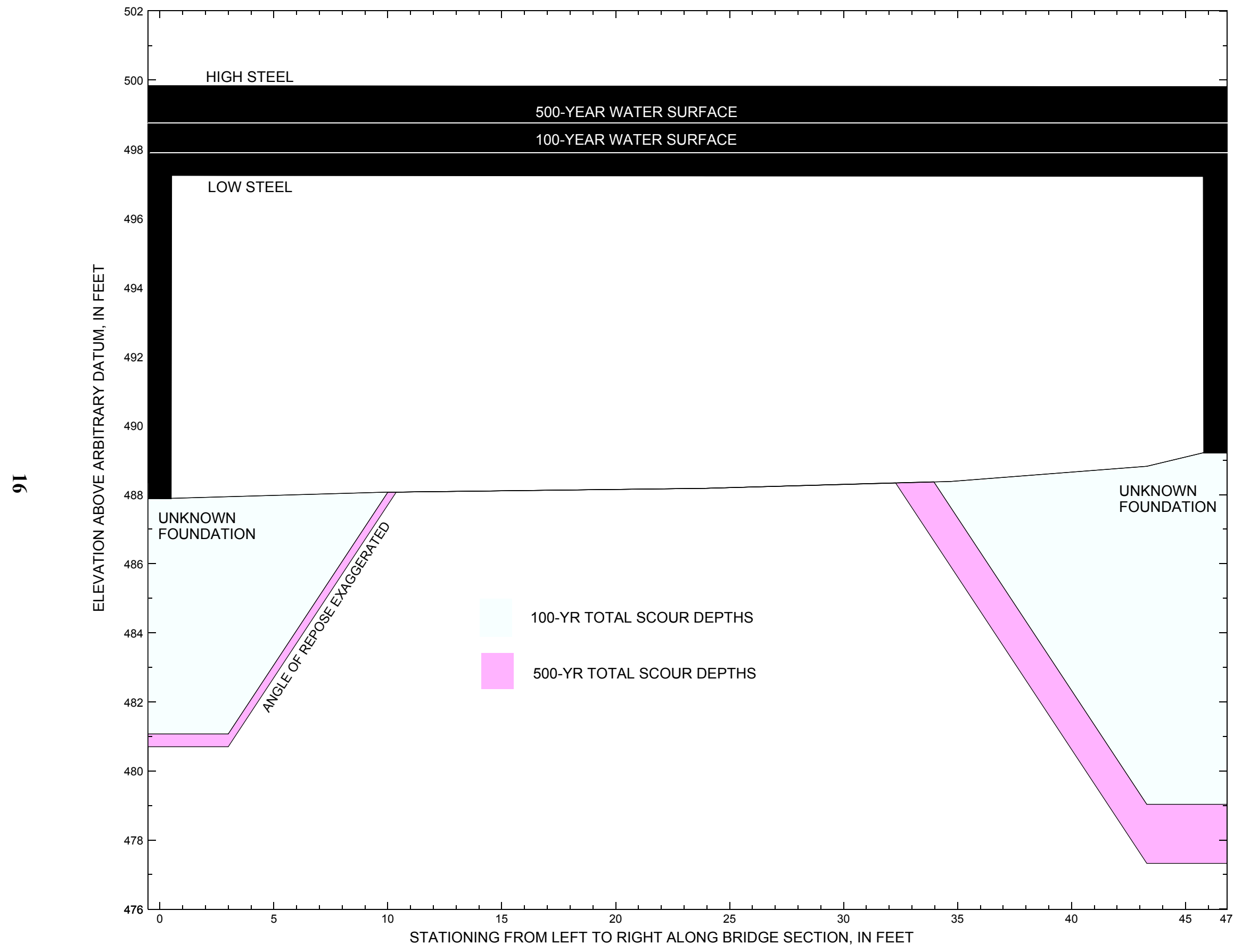

Figure 8. Scour elevations for the 100-yr and 500-yr discharges at structure BRIDTH00530049 on town highway 53, crossing Ottauquechee River, Bridgewater, Vermont. 
Table 1. Remaining footing/pile depth at abutments for the 100-year discharge at structure BRIDTH00530049 on Town Highway 53, crossing Ottauquechee River, Bridgewater, Vermont.

[VTAOT, Vermont Agency of Transportation; --,no data]

\begin{tabular}{|c|c|c|c|c|c|c|c|c|c|c|c|}
\hline Description & Station $^{1}$ & $\begin{array}{l}\text { VTAOT } \\
\text { minimum } \\
\text { low-chord } \\
\text { elevation } \\
\text { (feet) }\end{array}$ & $\begin{array}{c}\text { Surveyed } \\
\text { minimum } \\
\text { low-chord } \\
\text { elevation }{ }^{2} \\
\text { (feet) }\end{array}$ & $\begin{array}{c}\text { Bottom of } \\
\text { footing } \\
\text { elevation } \\
\text { (feet) }\end{array}$ & $\begin{array}{c}\text { Channel } \\
\text { elevation at } \\
\text { abutment/ } \\
\text { pier }^{2} \\
\text { (feet) }\end{array}$ & $\begin{array}{l}\text { Contraction } \\
\text { scour depth } \\
\text { (feet) }\end{array}$ & $\begin{array}{l}\text { Abutment } \\
\text { scour } \\
\text { depth } \\
\text { (feet) }\end{array}$ & $\begin{array}{l}\text { Pier } \\
\text { scour } \\
\text { depth } \\
\text { (feet) }\end{array}$ & $\begin{array}{l}\text { Depth of } \\
\text { total scour } \\
\text { (feet) }\end{array}$ & $\begin{array}{c}\text { Elevation of } \\
\text { scour }^{2} \\
\text { (feet) }\end{array}$ & $\begin{array}{c}\text { Remaining } \\
\text { footing/pile } \\
\text { depth } \\
\text { (feet) }\end{array}$ \\
\hline \multicolumn{12}{|c|}{100 -yr. discharge is 4,800 cubic-feet per second } \\
\hline Left abutment & 0.0 & -- & 497.2 & -- & 487.9 & 0.0 & 6.8 & -- & 6.8 & 481.1 & -- \\
\hline Right abutment & 46.3 & -- & 497.2 & -- & 489.3 & 0.0 & 10.3 & -- & 10.3 & 479.0 & -- \\
\hline
\end{tabular}

1. Measured along the face of the most constricting side of the bridge.

2. Arbitrary datum for this study.

Table 2. Remaining footing/pile depth at abutments for the 500-year discharge at structure BRIDTH00530049 on Town Highway 53, crossing Ottauquechee River, Bridgewater, Vermont.

[VTAOT, Vermont Agency of Transportation; --, no data]

\begin{tabular}{|c|c|c|c|c|c|c|c|c|c|c|c|}
\hline Description & Station $^{1}$ & $\begin{array}{l}\text { VTAOT } \\
\text { minimum } \\
\text { low-chord } \\
\text { elevation } \\
\text { (feet) }\end{array}$ & $\begin{array}{c}\text { Surveyed } \\
\text { minimum } \\
\text { low-chord } \\
\text { elevation }{ }^{2} \\
\text { (feet) }\end{array}$ & $\begin{array}{c}\text { Bottom of } \\
\text { footing } \\
\text { elevation } \\
\text { (feet) }\end{array}$ & $\begin{array}{c}\text { Channel } \\
\text { elevation at } \\
\text { abutment/ } \\
\text { pier }^{2} \\
\text { (feet) }\end{array}$ & $\begin{array}{l}\text { Contraction } \\
\text { scour depth } \\
\text { (feet) }\end{array}$ & $\begin{array}{l}\text { Abutment } \\
\text { scour } \\
\text { depth } \\
\text { (feet) }\end{array}$ & $\begin{array}{l}\text { Pier } \\
\text { scour } \\
\text { depth } \\
\text { (feet) }\end{array}$ & $\begin{array}{l}\text { Depth of } \\
\text { total scour } \\
\text { (feet) }\end{array}$ & $\begin{array}{c}\text { Elevation of } \\
\text { scour }^{2} \\
\text { (feet) }\end{array}$ & $\begin{array}{c}\text { Remaining } \\
\text { footing/pile } \\
\text { depth } \\
\text { (feet) }\end{array}$ \\
\hline \multicolumn{12}{|c|}{500 -yr. discharge is 6,500 cubic-feet per second } \\
\hline Left abutment & 0.0 & -- & 497.2 & -- & 487.9 & 0.0 & 7.2 & -- & 7.2 & 480.7 & -- \\
\hline Right abutment & 46.3 & -- & 497.2 & -- & 489.3 & 0.0 & 12.0 & -- & 12.0 & 477.3 & -- \\
\hline
\end{tabular}

1. Measured along the face of the most constricting side of the bridge.

2. Arbitrary datum for this study. 


\section{SELECTED REFERENCES}

Arcement, G.J., Jr., and Schneider, V.R., 1989, Guide for selecting Manning's roughness coefficients for natural channels and flood plains: U.S. Geological Survey Water-Supply Paper 2339, 38 p.

Barnes, H.H., Jr., 1967, Roughness characteristics of natural channels: U.S. Geological Survey Water-Supply Paper 1849, 213 p.

Brown, S.A. and Clyde, E.S., 1989, Design of riprap revetment: Federal Highway Administration Hydraulic Engineering Circular No. 11, Publication FHWA-IP-89-016, 156 p.

Federal Highway Administration, 1983, Runoff estimates for small watersheds and development of sound design: Federal Highway Administration Report FHWA-RD-77-158

Federal Emergency Management Agency, 1980, Flood Insurance Study, Town of Bridgewater, Windsor County, Vermont: Washington, D.C., January 1980.

Froehlich, D.C., 1989, Local scour at bridge abutments in Ports, M.A., ed., Hydraulic Engineering--Proceedings of the 1989 National Conference on Hydraulic Engineering: New York, American Society of Civil Engineers, p. 13-18.

Hayes, D.C.,1993, Site selection and collection of bridge-scour data in Delaware, Maryland, and Virginia: U.S. Geological Survey WaterResources Investigation Report 93-4017, 23 p.

Johnson, C.G. and Tasker, G.D.,1974, Progress report on flood magnitude and frequency of Vermont streams: U.S. Geological Survey Open-File Report 74-130, 37 p.

Lagasse, P.F., Schall, J.D., Johnson, F., Richardson, E.V., Richardson, J.R., Chang, F., 1991, Stream Stability at Highway Structures: Federal Highway Administration Hydraulic Engineering Circular No. 20, Publication FHWA-IP-90-014, 195 p.

Laursen, E.M., 1960, Scour at bridge crossings: Journal of the Hydraulics Division, American Society of Civil Engineers, v. 86, no. HY2, p. 39-53.

Potter, W. D., 1957a, Peak rates of runoff in the Adirondack, White Mountains, and Maine woods area, Bureau of Public Roads

Potter, W. D., 1957b, Peak rates of runoff in the New England Hill and Lowland area, Bureau of Public Roads

Richardson, E.V., and Davis, S.R., 1995, Evaluating scour at bridges: Federal Highway Administration Hydraulic Engineering Circular No. 18, Publication FHWA-IP-90-017, 204 p.

Richardson, E.V., Harrison, L.J., Richardson, J.R., and Davis, S.R., 1993, Evaluating scour at bridges: Federal Highway Administration Hydraulic Engineering Circular No. 18, Publication FHWA-IP-90-017, 131 p.

Richardson, E.V., Simons, D.B., and Julien, P.Y., 1990, Highways in the river environment: Federal Highway Administration Publication FHWA-HI-90-016.

Ritter, D.F., 1984, Process Geomorphology: W.C. Brown Co., Debuque, Iowa, 603 p.

Shearman, J.O., 1990, User's manual for WSPRO--a computer model for water surface profile computations: Federal Highway Administration Publication FHWA-IP-89-027, 187 p.

Shearman, J.O., Kirby, W.H., Schneider, V.R., and Flippo, H.N., 1986, Bridge waterways analysis model; research report: Federal Highway Administration Publication FHWA-RD-86-108, 112 p.

Talbot, A.N., 1887, The determination of water-way for bridges and culverts.

U.S. Department of Transportation, 1993, Stream stability and scour at highway bridges, Participant Workbook: Federal Highway Administration Publication FHWA HI-91-011.

U.S. Geological Survey, 1966, Plymouth, Vermont 7.5 Minute Series quadrangle map: U.S. Geological Survey Topographic Maps, Photo inspected 1983, Scale 1:24,000. 


\section{APPENDIX A: \\ WSPRO INPUT FILE}




\section{WSPRO INPUT FILE}

J1

J3

*

Q

SK

*

XS

GR

GR

GR

GR

$\mathrm{N}$

SA

XS

*

BR

GR

GR

GR

$\mathrm{N}$

CD

*

XR

GR

GR

GR

*

AS

GR

GR

GR

GR

GR

$\mathrm{N}$

SA

*

HP 1 BRIDG

HP 2 BRIDG

HP 2 RDWAY

HP 1 APPRO

HP 2 APPRO

*

HP 1 BRIDG

HP 2 BRIDG

HP 2 RDWAY

HP 1 APPRO

HP 2 APPRO

U.S. GEOLOGICAL SURVEY WSPRO INPUT FILE brid049.wsp CREATED ON 20-APR-95 FOR BRIDGE BRIDTH00530049 USING FILE brid049.dca N. Branch Ottauquechee River, TH 53, Town of Bridgewater

* $* 0.002$

$\begin{array}{lllllllllllllllllllll}6 & 29 & 30 & 552 & 553 & 551 & 5 & 16 & 17 & 13 & 3 & * & 15 & 14 & 23 & 21 & 11 & 12 & 4 & 7 & 3\end{array}$

$4800 \quad 6500 \quad 2502$

$0.0075 \quad 0.0075 \quad 0.0075$

$\operatorname{EXITX} \quad-67$

$\begin{array}{rrrr}-127.3, & 503.03 & -107.4, & 495.06 \\ -50.8, & 495.85 & -13.4, & 495.27 \\ 13.6, & 487.59 & 22.5, & 487.60 \\ 50.1, & 493.71 & 91.0, & 495.37 \\ 0.035 & 0.046 & 0.035 \\ -13 . & 50.1 & \end{array}$

$-84.3,495.26$

$0.0,488.30$

$33.2,487.72$

$188.5,498.30$

$-62.6,493.34$

$6.1,487.66$

$35.8,488.33$

$247.9,512.48$

RDWAY $\quad 8 \quad 14.0 \quad 2$

$-98.4,503.32$

$46.8,499.81$

$-78.9,494.99$

$-57.0,495.77$

$0.0,499.84$
$231.1,499.19$

$281.3,512.41$

$129.5,494.85$

$162.4,499.45$

$0.0,499.84$
$231.1,499.19$

$34.7,488.38$

$43.3,488.82$

$0.0,497.23$

69

$-76.8,506.89$

$-57.9,495.10$

$-36.2,496.62$

$-13.6,496.33$

$0.0,489.11$

$4.4,488.30$

$12.9,488.50$

$-9.5,494.12$

$30.5,488.36$

$39.7,488.94$

$44.5,490.24$

$57.7,495.61$

$114.1,494.98$

$153.7,495.10$

$188.1,500.82$

$264.6,506.08$

$286.5,514.39$

0.035

0.046

0.035

$$
\begin{array}{ll}
-9 . & 57.7
\end{array}
$$

497.231497 .23

497.23 * 3254

498.15 * 11555

498.541498 .54

498.54 * 4800

497.231497 .23

497.23 * 3923

498.90 * 2569

499.361499 .36

499.36 * 6500 


\section{APPENDIX B: \\ WSPRO OUTPUT FILE}




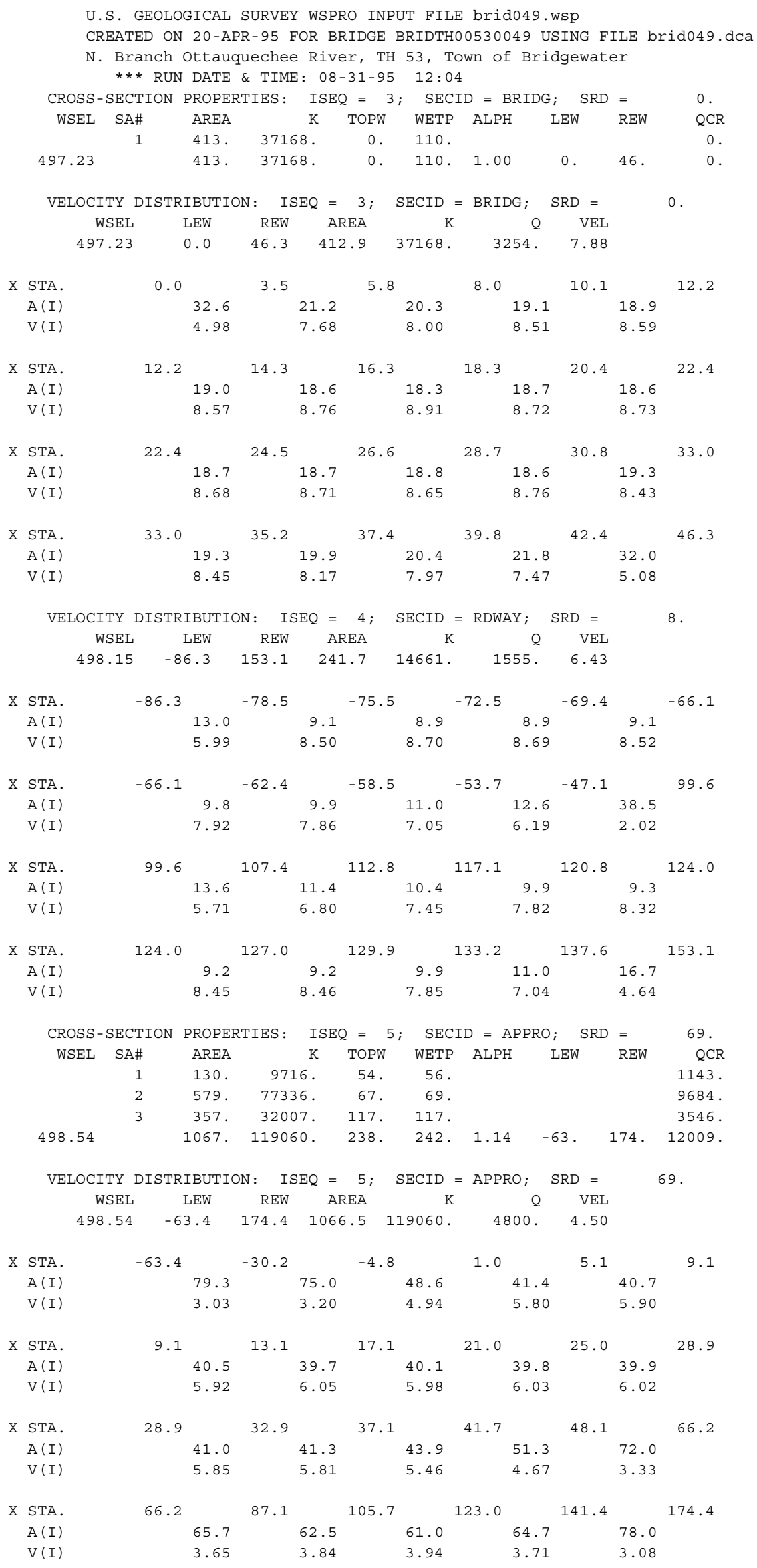


WSPRO OUTPUT FILE (continued)

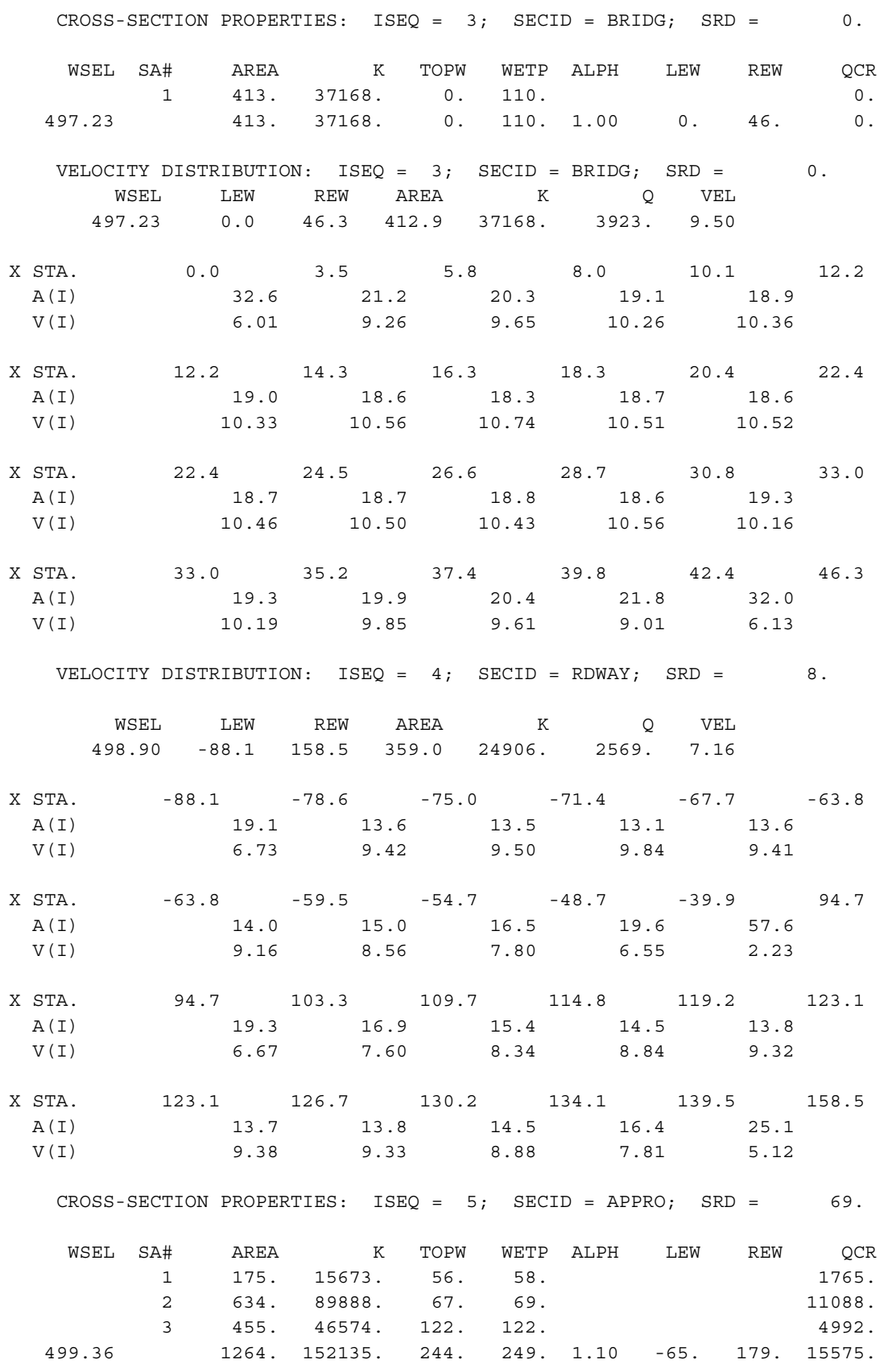

VELOCITY DISTRIBUTION $: \quad$ ISEQ $=5 ; \quad$ SECID $=$ APPRO $; \quad$ SRD $=69$.

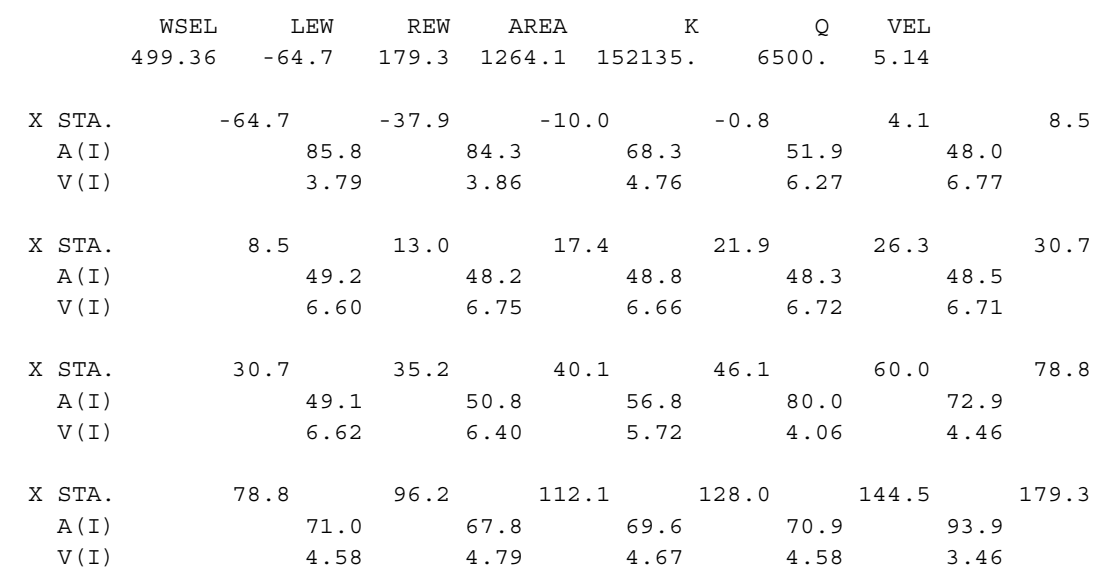


WSPRO OUTPUT FILE (continued)

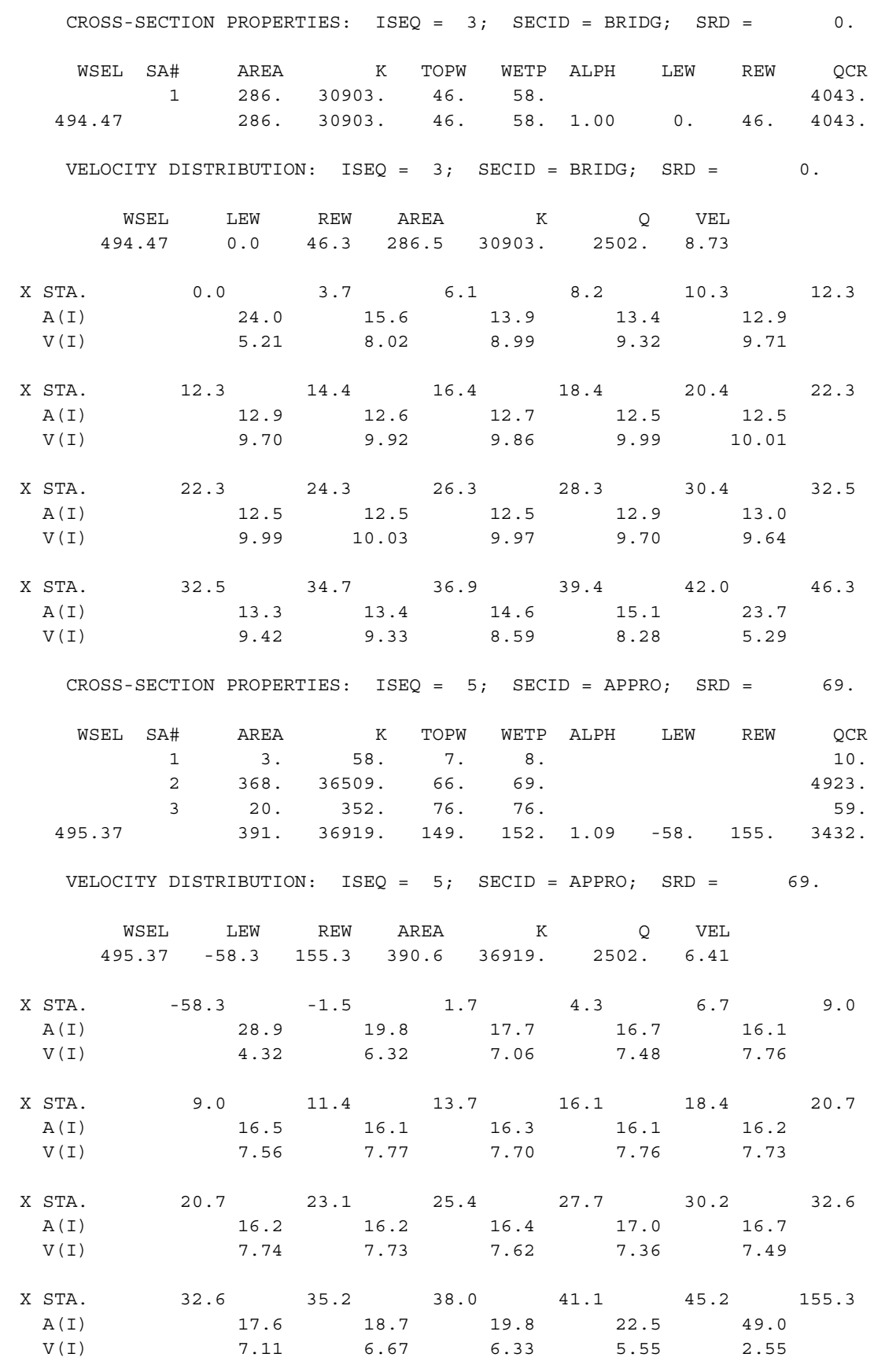


WSPRO OUTPUT FILE (continued)

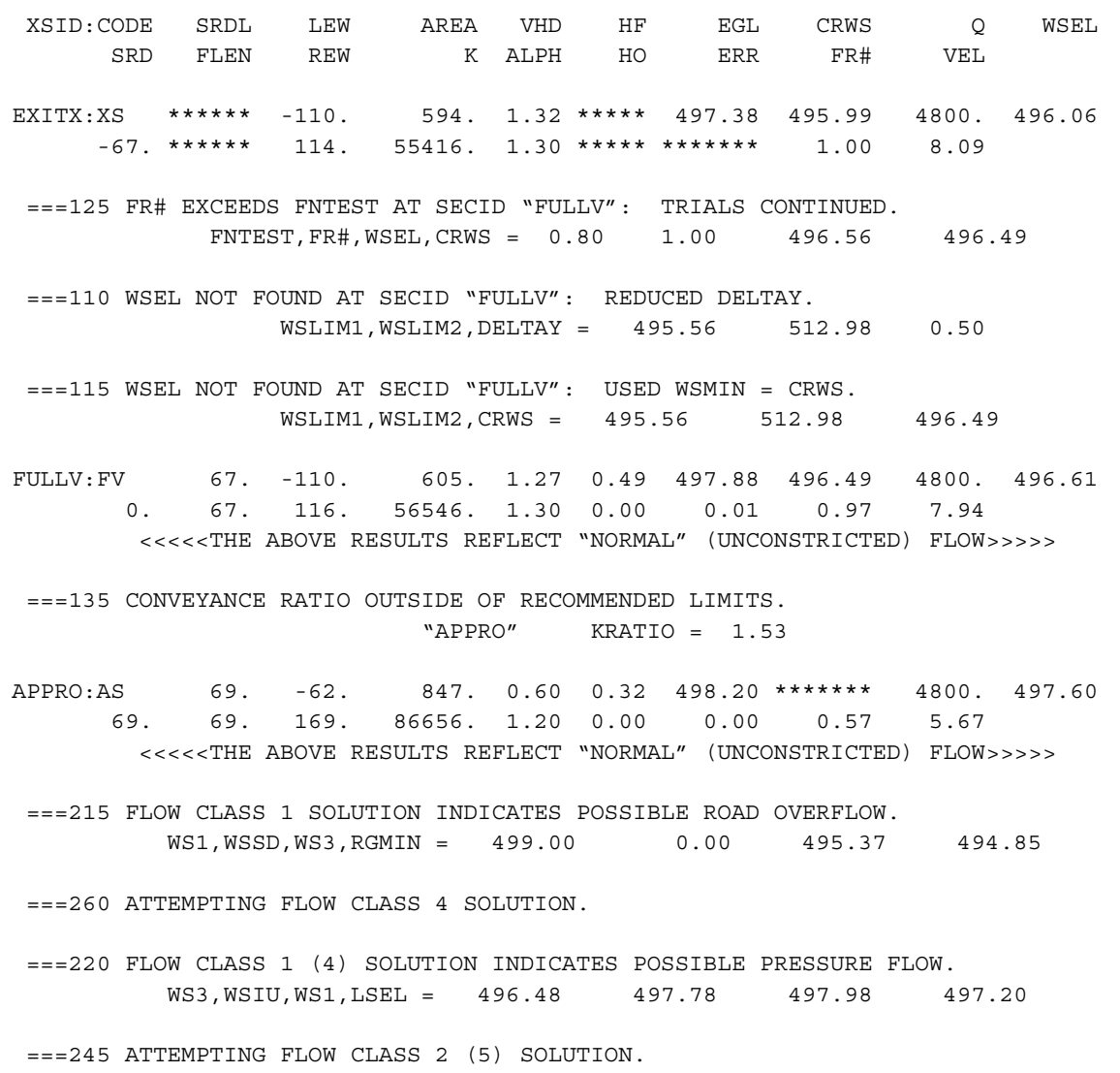


WSPRO OUTPUT FILE (continued)

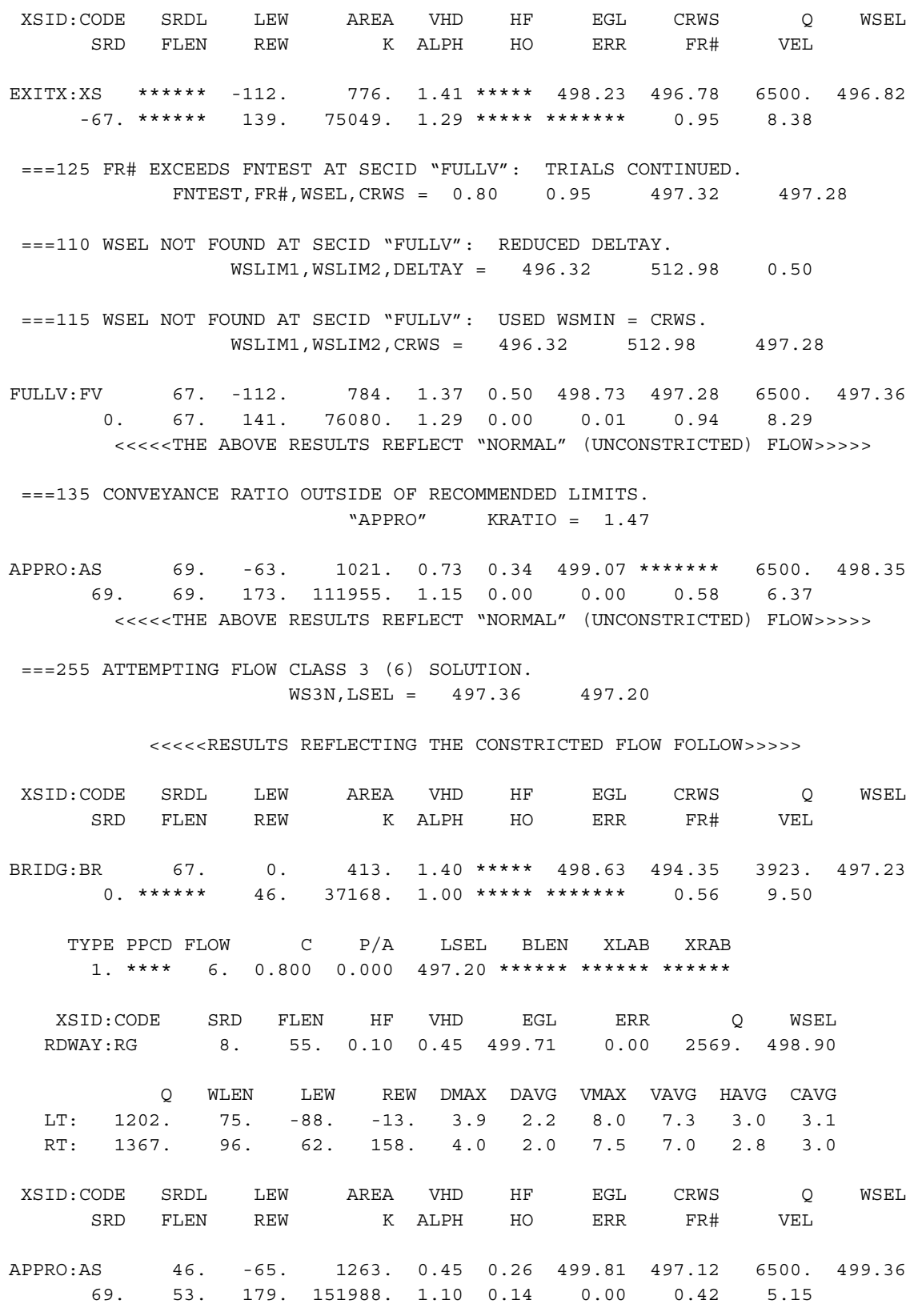

FIRST USER DEFINED TABLE.

\begin{tabular}{|c|c|c|c|c|c|c|c|c|}
\hline XSID : CODE & SRD & LEW & REW & $Q$ & $\mathrm{~K}$ & AREA & VEL & WSEL \\
\hline EXITX:XS & -67 & -112. & 139. & 6500. & 75049 . & 776. & 8.38 & 496.82 \\
\hline FULLV : FV & 0 & -112. & 141. & 6500. & 76080. & 784. & 8.29 & 497.36 \\
\hline BRIDG : BR & 0 . & 0 . & 46. & 3923. & 37168 . & 413. & 9.50 & 497.23 \\
\hline RDWAY : RG & $8 . *$ & $\star \star \star \star * \star$ & 1202 . & 2569 . * & $\star \star \star \star \star * \star * \star *$ & $* * * * *$ & 2.00 & 498.90 \\
\hline APPRO:AS & 69. & -65 & 179. & 6500. & 151988. & 1263. & 5.15 & 499.36 \\
\hline
\end{tabular}

SECOND USER DEFINED TABLE.

\begin{tabular}{|c|c|c|c|c|c|c|c|c|c|}
\hline XSID : CODE & CRWS & FR\# & YMIN & YMAX & $\mathrm{HF}$ & $\mathrm{HO}$ & VHD & EGL & WSEL \\
\hline EXITX:XS & 496.78 & 0.95 & 487.59 & 512.48 * & $* \star * \star * *$ & $\star * \star * *$ & 1.41 & 498.23 & 496.82 \\
\hline FULLV : FV & 497.28 & 0.94 & 488.09 & 512.98 & 0.50 & 0.00 & 1.37 & 498.73 & 497.36 \\
\hline BRIDG : BR & 494.35 & 0.56 & 487.88 & 497.23 * & $* \star \star * \star *$ & $\star \star \star \star *$ & 1.40 & 498.63 & 497.23 \\
\hline RDWAY : RG & 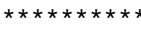 & $\star \star \star \star *$ & 494.85 & 512.41 & $0.10 *$ & $\star \star \star \star \star *$ & 0.45 & 499.71 & 498.90 \\
\hline APPRO: AS & 497.12 & 0.42 & 488.30 & 514.39 & 0.26 & 0.14 & 0.45 & 499.81 & 499.36 \\
\hline
\end{tabular}


WSPRO OUTPUT FILE (continued)

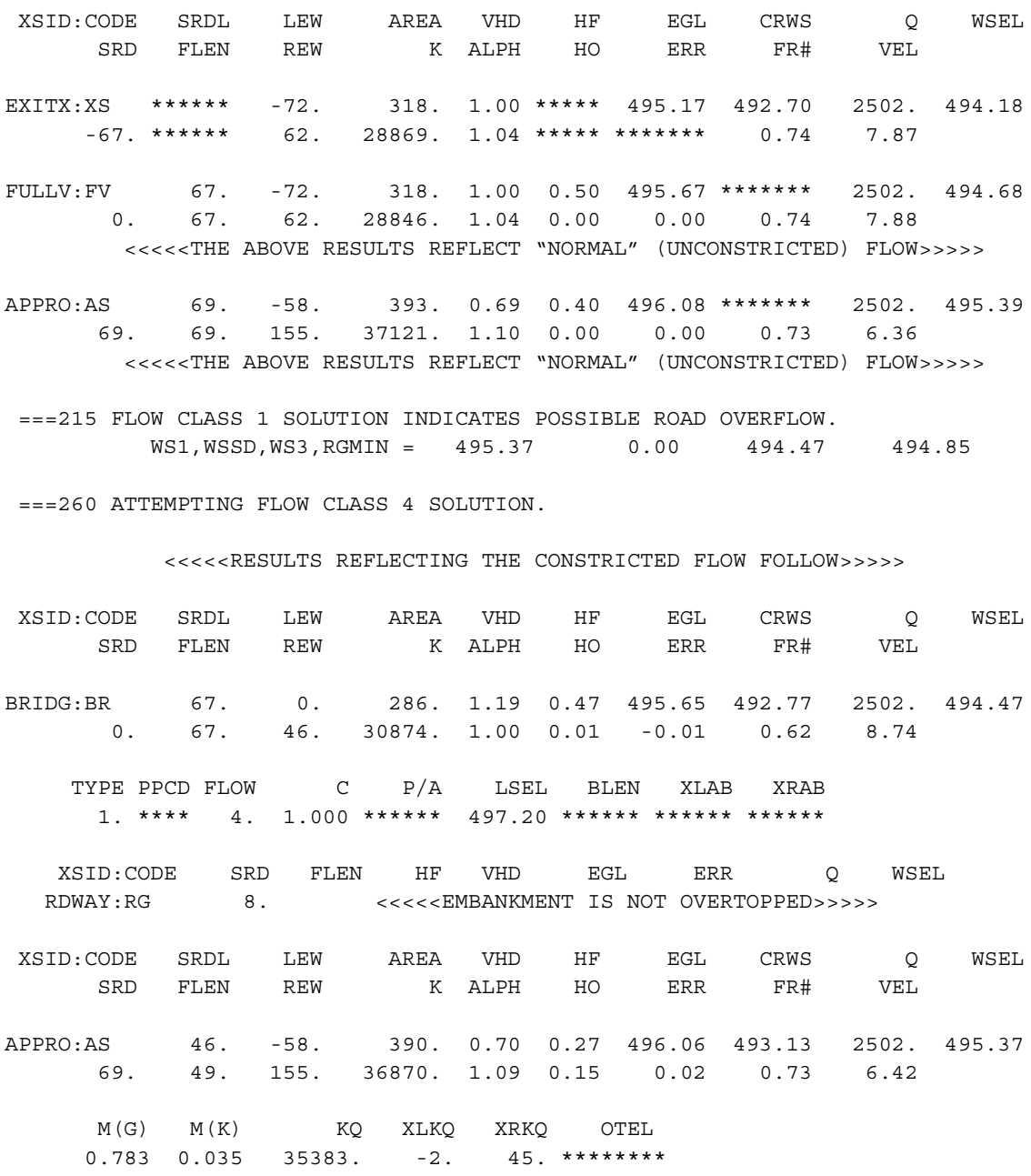

FIRST USER DEFINED TABLE.

\begin{tabular}{|c|c|c|c|c|c|c|c|c|}
\hline XSID : CODE & SRD & LEW & REW & $Q$ & K & AREA & VEL & WSEL \\
\hline EXITX:XS & -67 & -72. & 62. & 2502 . & 28869 . & 318. & 7.87 & 494.18 \\
\hline FULLV : FV & 0 . & -72. & 62. & 2502 . & 28846 . & 318. & 7.88 & 494.68 \\
\hline BRIDG : BR & 0 . & 0 . & 46. & 2502 . & 30874 . & 286 . & 8.74 & 494.47 \\
\hline RDWAY : RG & \multicolumn{3}{|c|}{ 8. $* * \star * \star * * * * \star * * * * * *$} & 0 . & 0 . & 0 . & \multicolumn{2}{|c|}{$2.00 * * * * * * * *$} \\
\hline APPRO : AS & 69. & -58 & 155. & 2502 . & 36870 . & 390. & 6.42 & 495.37 \\
\hline XSID : CODE & XLKQ & XRKQ & \multicolumn{2}{|c|}{$\mathrm{KQ}$} & & & & \\
\hline APPRO : AS & -2 . & 45 . & 35 & & & & & \\
\hline
\end{tabular}

SECOND USER DEFINED TABLE.

$\begin{array}{lcrrrrrrrr}\text { XSID : CODE } & \text { CRWS } & \text { FR\# } & \text { YMIN } & \text { YMAX } & \text { HF } & \text { HO } & \text { VHD } & \text { EGL } & \text { WSEL } \\ \text { EXITX:XS } & 492.70 & 0.74 & 487.59 & 512.48 * * * * * * * * * * * * & 1.00 & 495.17 & 494.18 \\ \text { FULLV : FV } & * * * * * * * * & 0.74 & 488.09 & 512.98 & 0.50 & 0.00 & 1.00 & 495.67 & 494.68 \\ \text { BRIDG : BR } & 492.77 & 0.62 & 487.88 & 497.23 & 0.47 & 0.01 & 1.19 & 495.65 & 494.47 \\ \text { RDWAY : RG } & * * * * * * * * * * * * * * * * & 494.85 & 512.41 & 0.26 * * * * * * & 0.70 & 495.79 * * * * * * * \\ \text { APPRO:AS } & 493.13 & 0.73 & 488.30 & 514.39 & 0.27 & 0.15 & 0.70 & 496.06 & 495.37\end{array}$




\section{APPENDIX C:}

\section{BED-MATERIAL PARTICAL-SIZE DISTRIBUTION}




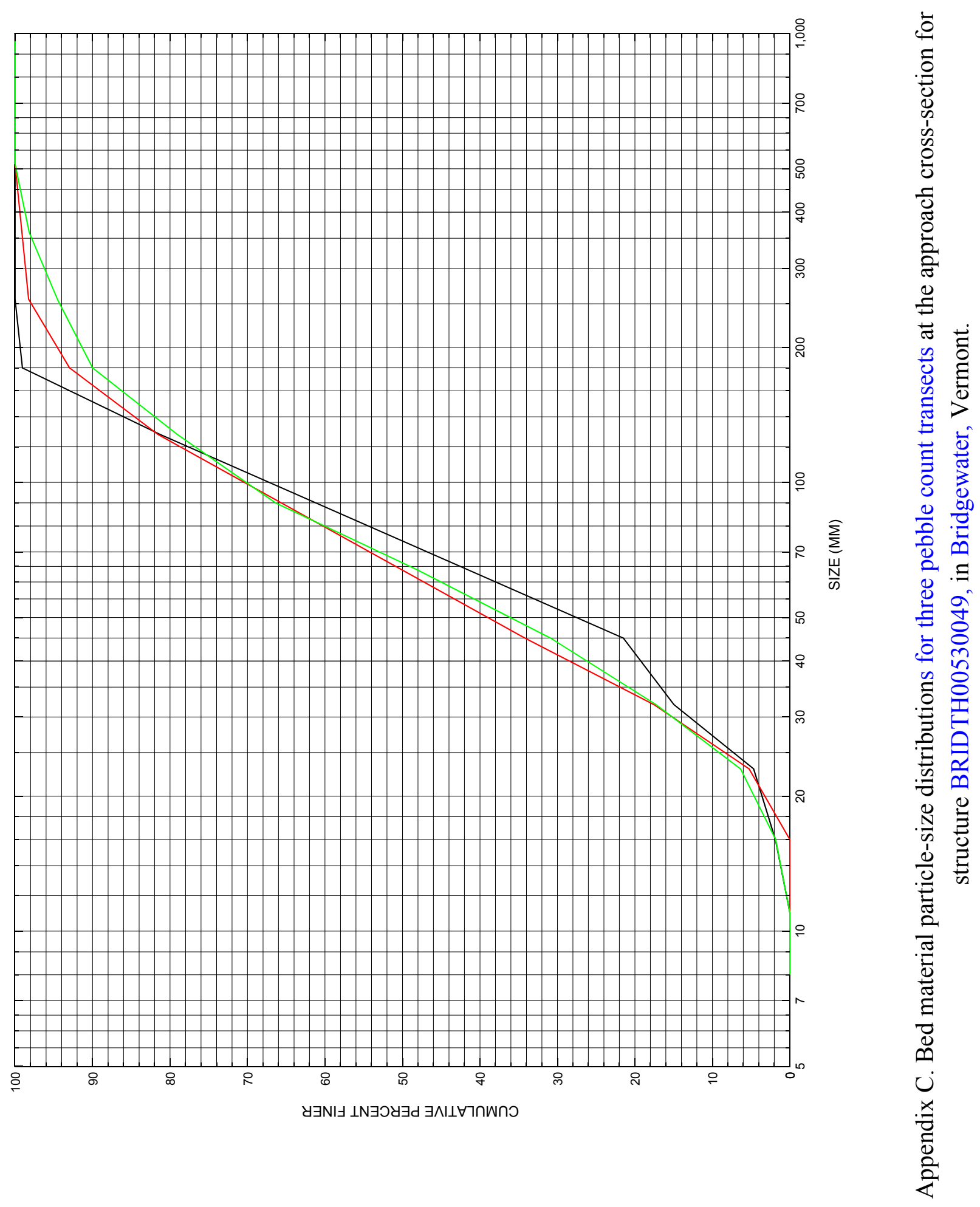




\section{APPENDIX D: \\ HISTORICAL DATA FORM}

